\title{
Effect of Flooding on Heavy Metals Contamination of Vistula Floodplain Sediments in Cracow; Historical Mining and Smelting as the Most Important Source of Pollution
}

\author{
Magdalena Strzebońska, Anna Kostka, Edeltrauda Helios-Rybicka, \\ Elżbieta Jarosz-Krzemińska*
}

Faculty of Geology, Geophysics and Environmental Protection, AGH University of Science and Technology, Al. Mickiewicza 30, 30-059 Cracow, Poland

Received: 25 September 2014

Accepted: 16 November 2014

\begin{abstract}
The discharge of high flood water (2010) into reservoirs located in the Upper Vistula River catchment and into the overloaded Vistula River channel may strongly affect water and sediment quality. To investigate the contamination of the flooded area in the center of Cracow, total of 32 sediment samples were collected along the length of the Vistula River and also from the cross section in the floodplain area. Additionally, 12 samples of the flooded sediments were collected along the Wilga River - a tributary of the Vistula located within the investigated area. The concentrations of $\mathrm{Zn}, \mathrm{Pb}, \mathrm{Cd}, \mathrm{Cu}, \mathrm{Mn}, \mathrm{Zn}$, and $\mathrm{Fe}$ in the bulk samples and size fraction $<20 \mu \mathrm{m}$ were studied. The metals concentration in the Vistula River flood sediment samples varied in wide ranges (mg/kg): Zn 59-1013, Pb 17-263, Cd 2.6-23, Mn 145-469, and Fe 0.70-3.59\%, and was considerably higher in the size fraction samples. The concentration of $\mathrm{Cu}$ was low and reached up to $40 \mathrm{mg} / \mathrm{kg}$. The highest amount of $\mathrm{Zn}$ was found in the sediment sample from the cross section, located $38 \mathrm{~m}$ from the Vistula River channel. Three-step sequential extraction revealed the most mobile metals in the sediment fraction $<20 \mu \mathrm{m}$, which were as follows: $\mathrm{Cd}$ (77\% of the total amount), $\mathrm{Pb}(55 \%)$, and $\mathrm{Zn}(42 \%)$. The contamination of the Wilga River flood sediments was lower when compared with Vistula River contamination.
\end{abstract}

Keywords: flood sediments, heavy metals, speciation, Upper Vistula River

\section{Introduction}

River bottom and flood sediments as well as soils in the historical recent mining and smelting areas need special management and monitoring. Heavy metals as the main contaminants of the soil-river system undergo many reactions and processes in the river channel, riverine floodplain, and estuarine. The fate and transport of heavy metals depends on topography, oxic-anoxic conditions and kinet-

*e-mail: elzbietajarosz@geol.agh.edu.pl ics of the sorption/desorption processes. Moreover, $\mathrm{pH}$, salinity, and the presence of organic matter, clay minerals, sulfates, and carbonates also affect metal mobility in floodplain sediments and soils [1-3].

For centuries Cracow has been exposed to floods caused by the high flush of the Vistula River. Among different types of floods in the Upper Vistula catchment, Cracow has been mostly exposed to a profuse rain, which persists from a few to several days and usually appears in summer months. During such rains in a large area of the Carpathian Mountains total precipitation ranges from 100 
to $600 \mathrm{~mm}$ and causes high and durable state of waters in the river valleys [4]. Two tributaries of the Vistula Riverthe Sola and Skawa Rivers-mostly contribute to the amount of flood water (total increase up to $70 \%$ ) in Cracow.

Flush waters in the Upper Vistula are reduced by Swinna Poreba dam on the Skawa River and by three water dams: Czaniec, Porąbka, and Tresna on the Sola River. In 2010 Cracow experienced four catastrophic floods, in May, June, July, and August/September, within the area of the Upper Vistula River [5]. Swinna Poreba dam played a significant role in flood wave attenuation in May 2010 (Fig. 1b). This specific dam collected ca. $60 \mathrm{mln} \mathrm{m}^{3}$ from the Skawa River flood wave, and caused a considerable reduction of the Vistula River flood wave in Cracow.
During floods all compartments of the river water system (water-suspended matter-bottom sediment) are exposed to contamination. Apart from huge amounts of waters the Upper Vistula River is also transporting high loads of sediments and suspended matter. The Vistula's tributaries mostly contribute to the size of the flood wave. Furthermore, since some of these tributaries flow through historical and present mining and smelting areas in Upper Silesia they transport substantial amounts of contaminants of industrial origin $[6,7]$. Since the Middle Ages Upper Silesia has been known for exploitation and smelting of $\mathrm{Pb}$ and Ag. At the beginning of the $19^{\text {th }}$ century a very modern Zn-industry started there, with $40 \%$ of the world production of this metal.

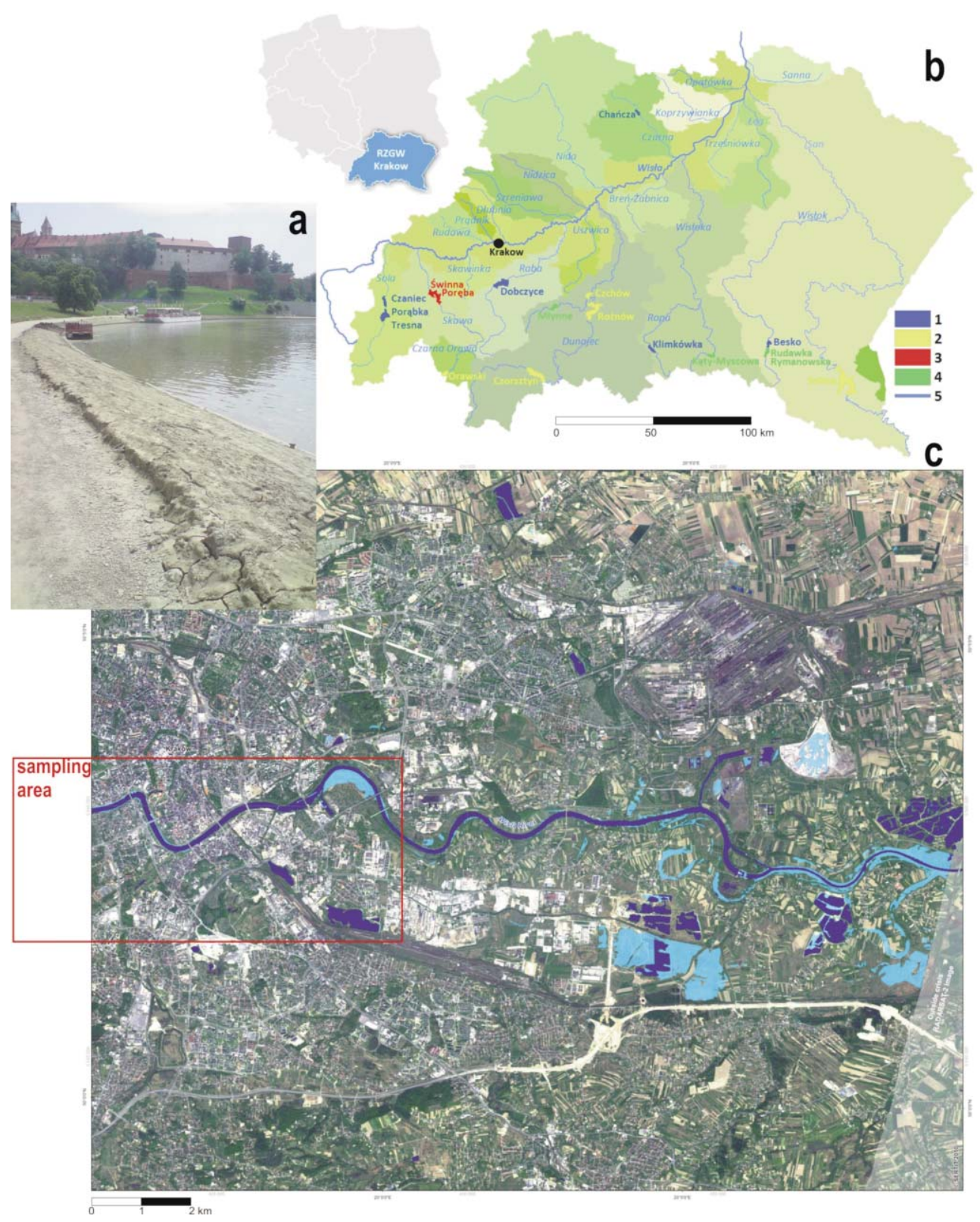

Fig. 1. Study area (a) photo of the Vistula River floodplain in Cracow; (b) Upper Vistula River catchment area: location of water dams according to the Regional Water Management Board (RZGW) [5]; (c) sampling area on the satellite image of the Vistula River flood in Cracow.

Explanations for (b): 1 - reservoirs under RZGW management, 2 - reservoirs under other units of management, 3 - reservoirs under construction, 4 - planned reservoirs, 5 - rivers. 
The Przemsza River is the most contaminated of all Vistula tributaries $[8,9]$. It is located in the area of $\mathrm{Zn}-\mathrm{Pb}$ mining and smelting and consequently is one of the most polluted rivers in Europe with respect to heavy metals.

Since sediments and soils act as sorbents for contaminants released from many sources, such as mines, industrial plants, or landfills leachates, they are often regarded as the "legacy of the past" [10-15].

The aims of the study were:

(i) To assess the main sources of heavy metals in the flood sediments

(ii) To establish heavy metals concentration in the flood sediment samples as well as in vertical profile

(iii) To determine mobility of heavy metals in the flood sediment samples

\section{Materials and Methods}

\section{Study Area}

Sediment samples (17 samples: V1-V17) were collected from the flooded area approximately $7 \mathrm{~km}$ from the outlet of the Rudawa River into the Vistula River and up to Nowa Huta - the district of Cracow (ca. $82 \mathrm{~km}$ of the Vistula River flow). Furthermore, 15 cross-section samples (VC1-VC15) were collected from the floodplain, at up to ca. $200 \mathrm{~m}$ from the riverbed. They were collected in proximity to the V17 sampling point, where the Vistula River dam was breached because of a very high river tidal wave. Additionally, 12 samples (W1-W12) of the sediments were collected from the Wilga River. The Sampling area is presented in Fig. 1c and sampling points are presented on Fig. 2a.

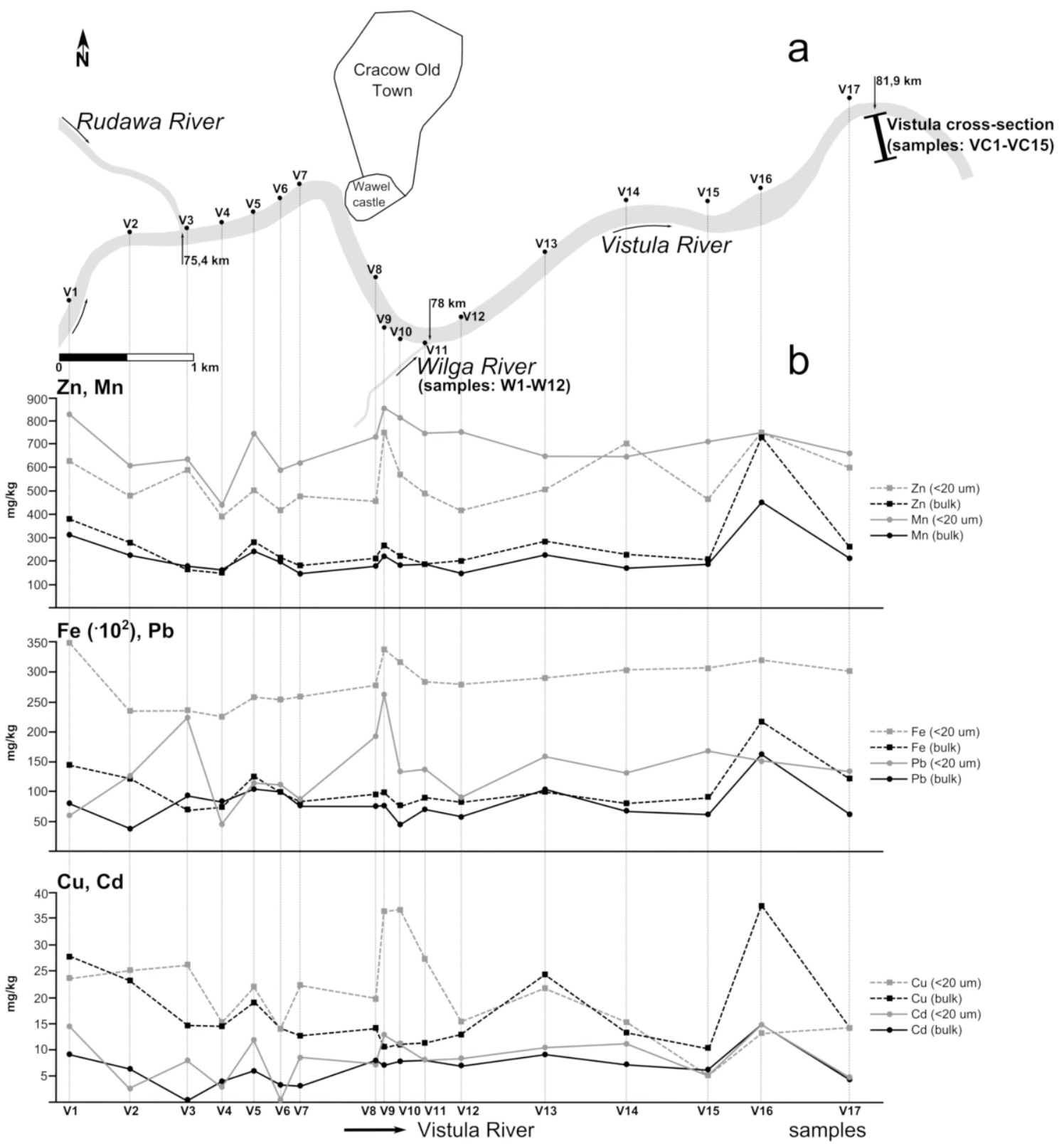

Fig. 2. Sampling points of the flood sediments along the Vistula River (V1-V17), Wilga River (W1-W12), the location of the cross section location samples (VC1-VC15) (a) and variability of $\mathrm{Zn}, \mathrm{Mn}, \mathrm{Pb}, \mathrm{Fe}, \mathrm{Cu}$, and $\mathrm{Cd}$ concentrations in bulk samples and the fraction $<20 \mu \mathrm{m}$ of flood sediments along the Vistula River (b). 
All samples were collected right after the flood disaster in May 2010, when the overflowed sediments deposited on the ground were still wet.

\section{Methods}

Sediment samples were collected manually in polyethylene containers up to a depth of $15 \mathrm{~cm}$, depending on the thickness of the overflow sediment. In the laboratory samples were homogenized, mixed with distilled water, and left for $24 \mathrm{hrs}$. They were stirred for 10 minutes and after wet sieving, the size fraction $<20 \mu \mathrm{m}$ was air dried and its mass percentage was calculated. The metals concentration was determined in both bulk and size fraction $<20 \mu \mathrm{m}$ samples of the flood sediments.

The acid digestion with $10 \mathrm{ml}$ of conc. $\mathrm{HNO}_{3}$ (according to EPA 3051) was performed on $0.5 \mathrm{~g}$ of each powdered flood sample in a closed vessel device using temperature control microwave heating (Milestone ETHOS lab station). The samples were aged for $3 \mathrm{hrs}$ and treated in a microwave oven according to the 2-step program: $1^{\text {st }}$ time $-5.5 \mathrm{~min}$ utes, the $2^{\text {nd }}-10$ minutes at $175^{\circ} \mathrm{C}$ and microwave power up to 1000 Watt in both steps. The heavy metals concentration was determined by AAS (Unicam ICE 3500).

The metal speciation in the selected flood sediment samples was determined using the $3^{\text {rd }}$ step sequential extraction procedure according to Quevauviller [16]. An additional $4^{\text {th }}$ step of the extraction with conc. $\mathrm{HNO}_{3}$ was performed in order to determine heavy metal content in remaining residuum. This step was commonly employed by many authors e.g. [17-20] as a supplementary step to the procedure.

To establish the salinity of the sediments, an aqueous leaching test was performed on bulk samples according to EN 12457:2006. Chloride content was determined via Mohr titrimetric method and sulfites were measured using the ICP-MS method (ELAN 6100).

Moreover, mineralogical composition in the selected sediment samples (V9 and V9 $<2 \mu \mathrm{m}, \mathrm{V} 16, \mathrm{VC} 12, \mathrm{VC} 15$ ) of size fraction $<20 \mu \mathrm{m}$ was determined using powder $\mathrm{X}$ ray diffraction (PXRD) followed by SEM-EDS analysis. $\mathrm{X}$-ray diffraction was performed for an air-dry powder sample using a Philips PW 3020 apparatus with the following parameters: $\mathrm{Cu} \mathrm{k \alpha}, 35 \mathrm{kV}, 30 \mathrm{~mA}$; step-by-step $0.05^{\circ} 2 \theta, 1 \mathrm{~s} / \mathrm{step}$. The $\mathrm{d}$ values obtained from the X-ray pattern were used for identification of mineral phases of the studied sample, according to the ICDD (International Centre for Diffraction Data) catalog and the computer program XRAYAN. In order to eliminate the influence of the apparatus factors on the intensity of the $\mathrm{X}$-ray escape peaks, the I0 regulation relative to standard quartz sample was made before sample measurement. The scanning electron microscopy analysis was performed using FEI Quanta 200 FEG SEM, equipped with a chemical composition analysis system based on energy dispersion spectroscopy EDS-EDAX.

Additionally, the content of carbonates in the samples were measured using the gas volumetric Scheibler method.

\section{Data Quality}

Method precision was verified by checking repeatability. The assay of heavy metals was determined in six samples of sediments. The analysis was performed on bulk samples and on fraction $<20 \mu \mathrm{m}$ according to the conditions described in the analytical method. The arithmetic mean results of assay and its standard deviation are presented below:

- Bulk sample [mg/kg]: Zn 272 $\pm 6, \mathrm{~Pb} 30.1 \pm 5.5, \mathrm{Cd}$ $3.82 \pm 0.87, \mathrm{Cu} 16.9 \pm 0.9, \mathrm{Mn} 254 \pm 11$, Fe 9564 \pm 300 ;

- Fraction $<20 \mu \mathrm{m}[\mathrm{mg} / \mathrm{kg}]$ : Zn $635 \pm 14, \mathrm{~Pb} 89.3 \pm 3.0, \mathrm{Cd}$

$7.83 \pm 0.62, \mathrm{Cu} 41.4 \pm 0.7, \mathrm{Mn} 892 \pm 6$, Fe $26038 \pm 828$.

The reproducibility of the data from multiplied measurements was estimated as $<5 \%$.

\section{Results}

\section{Physical-Chemical Parameters}

The $\mathrm{pH}$ of the sediment samples varied insignificantly and ranged from 7.5 to 7.8. The statistical parameters of the size fraction content and heavy metal concentration for the Vistula River flood sediment samples are shown in Table 1. The relative amount of the size fraction $<20 \mu \mathrm{m}$ in the samples collected along the Vistula River (V1-V17) ranged from 1.9 to $20.9 \mathrm{wt} \%$ and in the samples from the cross section (VC1-VC15) ranged from 1.0 to $26.7 \mathrm{wt} \%$. In the selected samples (V9, V16, VC12, VC15) clay fraction $<2 \mu \mathrm{m}$ was separated, but its content was rather low and varied from 1.52 to $5.77 \mathrm{wt} \%$.

\section{Mineralogical Composition}

PXRD analysis revealed smectite, illite and kaolinite as the main clay minerals in the sediment samples. Quartz, calcite, dolomite, feldspars and traces of goethite and hematite were also detected. Moreover, Ca-monosulfate (anhydrite) was present only in the selected flood sediment sample (Fig. 3), probably as a result of the reaction of $\mathrm{CaCO}_{3}$ with different forms of sulphur (both present in the sediments), during thermal treatment at $560^{\circ} \mathrm{C}$. The content of carbonates (mainly calcite) detected via the Scheibler method varied from $2.2 \%$ to $3.5 \%$.

\section{SEM-EDX Results}

The scanning electron micrographs and X-ray energy dispersive spectrum images presented in Fig. 4 revealed that:

(a) $\mathrm{Pb}$ is present in carbonate form (cerussite) and is visible as aggregate among silicates

(b) Cr mineral phase - chromite is adhered to Fe-oxides

(c) Anhydrite grains or aggregates among fine particles of aluminosilicates

(d) Yttrium grain adhered to aluminosilicate and to $\mathrm{Ca}-\mathrm{Mg}$ carbonate. The presence of Yttrium (Y) was also was confirmed by the results of the aqueous leaching solution. 
Table 1. Statistical parameters of heavy metal concentrations in the flood sediments of the Vistula and Wilga Rivers in the Krakow area.

\begin{tabular}{|c|c|c|c|c|c|c|c|c|c|c|c|c|c|}
\hline \multirow{3}{*}{ Parameter } & \multirow{3}{*}{$\begin{array}{c}<20 \mathrm{~mm} \mathrm{fr} . \\
\%\end{array}$} & \multicolumn{2}{|r|}{$\mathrm{Zn}$} & \multicolumn{2}{|c|}{$\mathrm{Pb}$} & \multicolumn{2}{|c|}{$\mathrm{Cd}$} & \multicolumn{2}{|r|}{$\mathrm{Cu}$} & \multicolumn{2}{|r|}{$\mathrm{Mn}$} & \multirow{2}{*}{\multicolumn{2}{|c|}{$\frac{\mathrm{Fe}}{\%}$}} \\
\hline & & \multicolumn{10}{|c|}{$\mathrm{mg} / \mathrm{kg}$} & & \\
\hline & & Bulk & $<20 \mathrm{~mm}$ & Bulk & $<20 \mathrm{~mm}$ & Bulk & $<20 \mathrm{~mm}$ & Bulk & $<20 \mathrm{~mm}$ & Bulk & $<20 \mathrm{~mm}$ & Bulk & $<20 \mathrm{~mm}$ \\
\hline \multicolumn{14}{|c|}{ Vistula River (samples V1-V17) } \\
\hline Maximum & 20.92 & 728 & 754 & 163 & 263 & 14.9 & 14.9 & 37 & 37 & 452 & 856 & 2.16 & 3.47 \\
\hline Minimum & 1.89 & 153 & 388 & 38 & 46 & $<\mathrm{QL}$ & 2.6 & 10 & 5 & 145 & 443 & 0.70 & 2.25 \\
\hline Arithm. mean & 9.91 & 262 & 540 & 80 & 137 & 6.6 & 8.7 & 17 & 21 & 214 & 692 & 1,04 & 2.83 \\
\hline Median & 9.14 & 223 & 502 & 75 & 132 & 7.0 & 8.3 & 14 & 22 & 192 & 708 & 0.95 & 2.83 \\
\hline $\mathrm{SD}$ & 4.83 & 132 & 114 & 29 & 55 & 3.2 & 3.8 & 7 & 8 & 74 & 102 & 0.35 & 0.36 \\
\hline \multicolumn{14}{|c|}{ Vistula River Cross-section (samples VC1-VC15) } \\
\hline Maximum & 26.68 & 591 & 1013 & 137 & 227 & 23.3 & 16.6 & 31 & 40 & 469 & 979 & 2.16 & 3.59 \\
\hline Minimum & 0.60 & 59 & 352 & $<\mathrm{QL}$ & 17 & $<\mathrm{QL}$ & 3.0 & $<\mathrm{QL}$ & 17 & 17 & 605 & 0.15 & 2.61 \\
\hline Arithm. mean & 13.84 & 309 & 558 & 70 & 118 & 7.7 & 10.3 & 15 & 29 & 281 & 770 & 1.25 & 2.93 \\
\hline Median & 17.04 & 288 & 558 & 85 & 118 & 6.0 & 10.9 & 16 & 32 & 316 & 793 & 1.44 & 2.93 \\
\hline SD & 8.72 & 152 & 162 & 45 & 57 & 7.0 & 3.7 & 9 & 8 & 144 & 113 & 0.58 & 0.25 \\
\hline \multicolumn{14}{|c|}{ Wilga River (samples W1-W12) } \\
\hline Maximum & 55.25 & 146 & 352 & 62 & 227 & 6.5 & 8.7 & 56 & 115 & 353 & 686 & 1.55 & 3.08 \\
\hline Minimum & 4.07 & 12 & 119 & $<\mathrm{QL}$ & 49 & $<\mathrm{QL}$ & $<\mathrm{QL}$ & $<\mathrm{QL}$ & 24 & 99 & 376 & 0.35 & 1.99 \\
\hline Arithm. mean & 19.42 & 51 & 178 & 24 & 99 & 2.0 & 2.0 & 13 & 41 & 217 & 473 & 0.83 & 2.31 \\
\hline Median & 13.42 & 43 & 154 & $<\mathrm{QL}$ & 77 & $<\mathrm{QL}$ & 1.2 & 10 & 29 & 234 & 452 & 0.85 & 2.17 \\
\hline SD & 16.00 & 36 & 70 & 30 & 58 & 2.7 & 2.6 & 14 & 27 & 82 & 82 & 0.37 & 0.32 \\
\hline $\begin{array}{l}\text { Geochemical } \\
\text { background }\end{array}$ & [21] & \multicolumn{2}{|r|}{95} & \multicolumn{2}{|r|}{20} & \multicolumn{2}{|c|}{0.3} & \multicolumn{2}{|r|}{45} & \multicolumn{2}{|r|}{850} & \multicolumn{2}{|r|}{4.7} \\
\hline $\begin{array}{l}\text { Local } \\
\text { background }\end{array}$ & [8] & \multicolumn{2}{|c|}{110} & \multicolumn{2}{|r|}{45} & \multicolumn{2}{|r|}{2} & \multicolumn{2}{|r|}{40} & \multicolumn{2}{|r|}{140} & \multicolumn{2}{|r|}{1.3} \\
\hline
\end{tabular}

$<\mathrm{QL}$ - below quantitive limit

\section{Heavy Metals Concentration}

The maximum concentration of metals in the bulk sediment samples and in the fraction $<20 \mu \mathrm{m}$ collected along the Vistula River were as follows (mg/kg): Zn 728 and 754, $\mathrm{Pb} 163$ and 263, Cd 14.9 in both samples, $\mathrm{Cu} 37$ (in both samples), Mn 452 and 856, Fe 3.47 and $2.16 \%$. The mean concentration of the investigated metals in the size fraction $<20 \mu \mathrm{m}$ was rather high and exceeded the background values introduced by Helios-Rybicka [8] (Table 1). Concentration of $\mathrm{Zn}$ was 540 [mg/kg], Pb 137 [mg/kg] and $\mathrm{Cd} 8.7[\mathrm{mg} / \mathrm{kg}]$. Metals concentration in the cross section samples (VC1-VC15) was comparable to its content in sediment samples, except for $\mathrm{Zn}$ concentration. According to the obtained results (Table 1) arithmetic mean concentration of all investigated metals were higher in fraction $<20 \mu \mathrm{m}$ rather than in bulk samples. The highest differences were observed for $\mathrm{Zn}, \mathrm{Pb}, \mathrm{Fe}, \mathrm{Mn}$, and in some samples for Cd (Figs. 2, 5).
Flood sediment samples from the Wilga River revealed lower mean metals concentration than the Vistula sediment sample, with the exception of $\mathrm{Cu}$ in the $<20 \mu \mathrm{m}$ sample (Table 1). However, the amount of fraction $<20 \mu \mathrm{m}$ was higher (mean value ca. $20 \mathrm{wt} \%$ ) in the Wilga than in the Vistula River sediment samples (mean values ca. $10 \mathrm{wt} \%$ and $14 \mathrm{wt} \%$ in the profile).

In general, in all bulk flood sediment samples the metals concentration was increasing with higher content of the $<20 \mu \mathrm{m}$ size fraction. The obtained results for $\mathrm{Zn}$ concentrations in the Vistula River flood sediments are consistent with the findings for both fine-grained fraction $<20 \mu \mathrm{m}$ and/or $<2 \mu \mathrm{m}$ published earlier [8, 22-24].

\section{Metals Speciation}

Chemical forms of metals were determined in the $<20 \mu \mathrm{m}$ size fraction of the samples V9, V16, VC15, and $\mathrm{VC} 12$, and additionally in the $<2 \mu \mathrm{m}$ fraction separated from V9 sample. 
The relative amounts of exchangeable and carbonate fractions (step I), which are the most mobile portion of the metal ions, were high and varied in wide ranges: $\mathrm{Cd} 51-$ $77 \%$, Zn 38-52\%, Pb 8-54\%, Cu 10-20\%, and Mn 37-57\% (Fig. 6). The highest concentration of $\mathrm{Pb}$ and $\mathrm{Zn}$ was associated with the reducible fraction, up to $71 \%$ of $\mathrm{Pb}$ and $31 \%$ of $\mathrm{Zn}$. The relative amounts of acid-extractable and -reducible fractions for $\mathrm{Cd}, \mathrm{Zn}$, and $\mathrm{Pb}$ were comparable with the amounts of these two fractions for Mn. Moreover, up to $55 \%$ of $\mathrm{Cu}$ was bound with $\mathrm{Fe}$ (hydro)oxides and sulfides (oxidizable fraction). Iron was the least mobile of all metals in the investigated samples and up to $72 \%$ of this metal was bound with residual fraction (step IV). Additionally, as presented in Fig. 6, 46\% of $\mathrm{Cu}$ remained immobile as well as $20 \%$ each of $\mathrm{Zn}$ and $\mathrm{Cd}$.

\section{Discussion}

During the 2010 flood high waters in the Upper Vistula were caused mainly by its Carpathian tributaries, which in spite of a few dam reservoirs (Fig. 1b) were not able to store so much water. Sediments re-deposited were contaminated mainly with $\mathrm{Zn}, \mathrm{Pb}$, and $\mathrm{Cd}$. High concentrations of these metals in the investigated sediments originate mostly from historical and recent mining, processing, and smelting of the $\mathrm{Zn}-\mathrm{Pb}$ ores deposited in the Przemsza River catchment. Obtained results revealed that the concentration of metals in the Vistula River flood sediment, both in bulk samples and in $<20 \mu \mathrm{m}$ fractions, were (mg/kg): $\mathrm{Zn} \mathrm{1013-59,} \mathrm{Pb} 263-17$, $\mathrm{Cd}$ 23.3-<QL, Mn 469-145, and Fe $3.59-0.70 \%$. Concentrations were considerably higher in the size fraction $<20 \mu \mathrm{m}$ than in bulk samples. The concentrations of $\mathrm{Zn}, \mathrm{Pb}$, and $\mathrm{Cd}$ in the flood sediment exceeded geochemical background values established by Turekian and Wedephol [21], as well as local background introduced by Helios Rybicka [8]. Obtained results can be compared to the previous studies $[8,25]$, which revealed that in the prehistorically fine-grained sediments of the Upper Vistula, $\mathrm{Zn}$ concentration was up to $190 \mathrm{mg} / \mathrm{kg}, \mathrm{Pb}$ up to $100 \mathrm{mg} / \mathrm{kg}$, and $\mathrm{Cd}$ up to $10 \mathrm{mg} / \mathrm{kg}$. However, in the younger alluvia, dated back to 150-200 years, the concentrations of these metals were as follows: $\mathrm{Zn} \mathrm{11,500} \mathrm{mg/kg,} \mathrm{Pb} \mathrm{1,745} \mathrm{mg/kg,}$ and $\mathrm{Cd} 625 \mathrm{mg} / \mathrm{kg}$. Moreover, the results of the research conducted for over 15 years (1991-2005) by Bojakowska and Gliwicz [26], showed that the mean Cd concentration in the sediments was $7.1 \mathrm{mg} / \mathrm{kg}$, while the highest was 135 $\mathrm{mg} / \mathrm{kg}$. The highest average $\mathrm{Cd}$ concentration (ca. 50 $\mathrm{mg} / \mathrm{kg}$ ) in the Vistula River sediments was found in Oświęcim - the sampling point located below the Przemsza River inflow, while the river section Tyniec-Niepołomice close to Cracow was considerably lower and reached 16.5 $\mathrm{mg} / \mathrm{kg}$.

Moreover, the results of Gueguen and Dominik [27] regarding the Upper Vistula River system revealed that $\mathrm{Pb}$ and $\mathrm{Cd}$ pollution was transported mostly in particulate form, $\mathrm{Cu}$ and $\mathrm{Mn}$ in dissolved form, and zinc $\mathrm{Zn}$ was showing an intermediate behavior. According to that study, the portion of metals in the colloid form was very low. That was probably due to an increase of Vistula water salinity, which has caused the release of some metals from this fraction by this desorption from colloid surfaces. These findings are convergent with the results of a laboratory experiment run on sediments at various salinities by Zhao et al. [28], which proved that heavy metals are mobilized from polluted sediments if they are exposed to increasing salinity. In general, the concentration of $\mathrm{Cl}^{-}$in the Vistula River water during the last decade was rather high, reaching up to $2000 \mathrm{mg} / \mathrm{L}$, (741 mg/L in 2011) while $\mathrm{SO}_{4}^{2--}$ concentration considerably decreased to $150 \mathrm{mg} / \mathrm{L}$ (147 mg/L in 2011) [29]. An elevated salinity of the Vistula River water, caused by dewatering of the coal mines, can influence the desorption processes, especially of $\mathrm{Cd}$ ions combined with exchangeable sites of fine-grained clay minerals. The metals can also precipitate or co-precipitate with carbonates (mainly calcite) present in the flood sediment samples.

In the current research the salinity of the flood sediments were determined by conducting aqueous leaching test. The results revealed that the concentrations of both suphates and chlorides in the aqueous leachates was low and did not

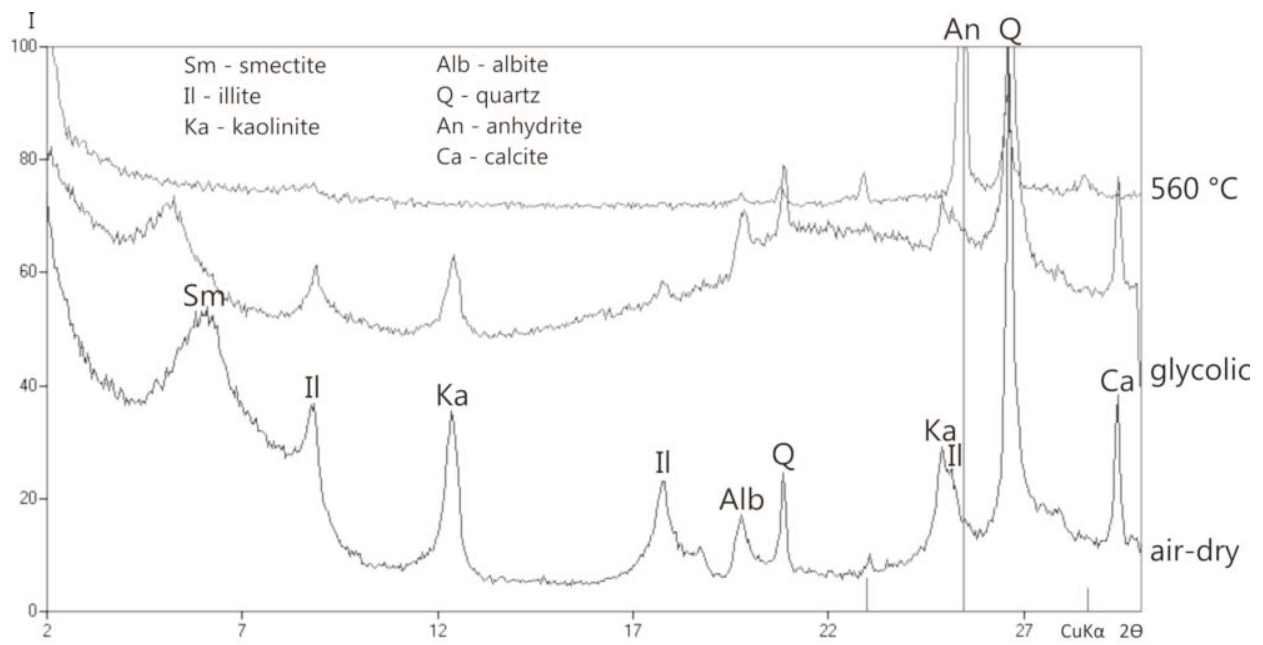

Fig. 3. X-Ray diffraction patterns of the $<2 \mu \mathrm{m}$ clay fraction of the Vistula River flood sediment selected sample (V9): air-dried, ethylene glycol-solvated, and heated at $560^{\circ} \mathrm{C}$. 
exceed permissible values according to Polish legislation [30]. The concentration of sulphates varied from 79.4 and $50.9 \mathrm{mg} / \mathrm{L}$ and chlorides varied from 4.6 and $3.8 \mathrm{mg} / \mathrm{L}$.

Release of metals from the flood sediments is determined mainly by oxidation/reduction conditions and chemical forms of metals. Bottom sediment being under reducing conditions can undergo oxidation processes when transported from the riverbed during a flood [25, 31-34]. Consequently, changing an anaerobic to aerobic condition in the bottom sediment will strongly increase the mobility of metals. According to the results of Helios-Rybicka [35, 36] and Aleksander-Kwaterczak [37] (Fig. 7), the mobile portions of $\mathrm{Pb}, \mathrm{Cd}$, and $\mathrm{Zn}$ were very low in the anoxic sediment samples of the Biała (BR) and Przemsza (PR) rivers. However, in the same sediment samples, which underwent oxidation, the mobile portion of metals significantly increased and reached up to $10 \%$ of $\mathrm{Zn}, 17 \% \mathrm{Cd}$, and $64 \%$ of $\mathrm{Pb}$. As reported by Violante et al. [38] and Magdi Selim [39], mobilization of the sediment-bound metals to the water column under oxidizing conditions occurs mainly during floods and dredging activities.
Current research conducted on the Vistula River flood sediments, which underwent oxidation, also confirmed high mobility of $\mathrm{Zn}$ and $\mathrm{Cd}$. Up to $70 \%$ of these metals were bound with exchangeable fractions. Moreover, $\mathrm{Pb}$ was bound with less mobile forms (up to $75 \%$ with reducible fraction), but in some cases the percentage of the exchangeable fraction is even equal to $55 \%$. Relatively small amounts of $\mathrm{Zn}, \mathrm{Cd}$, and $\mathrm{Pb}$ were therefore bound with the immobile fractions. From all metals in the investigated flood sediment samples, $\mathrm{Cd}$ is the most important one due to its high mobility and toxicity.

Clay minerals, present in the river sediments (Fig. 4) act as scavengers and as the source of metal ions in the wateraluvia soil system. Under reducing conditions, $\mathrm{S}^{2-}$ ions become released from clay minerals and precipitate as sulfides. These findings are consistent with the results of the Helios-Rybicka experimental study [40] on application of different clay minerals as metal donors for precipitation of their sulfide forms; eg. $\mathrm{Cu}$ as a rythmic formation of covellite with clay mineral, or $\mathrm{Fe}$ and $\mathrm{Pb}$ as double coating of pyrite and galena on silicate grain.
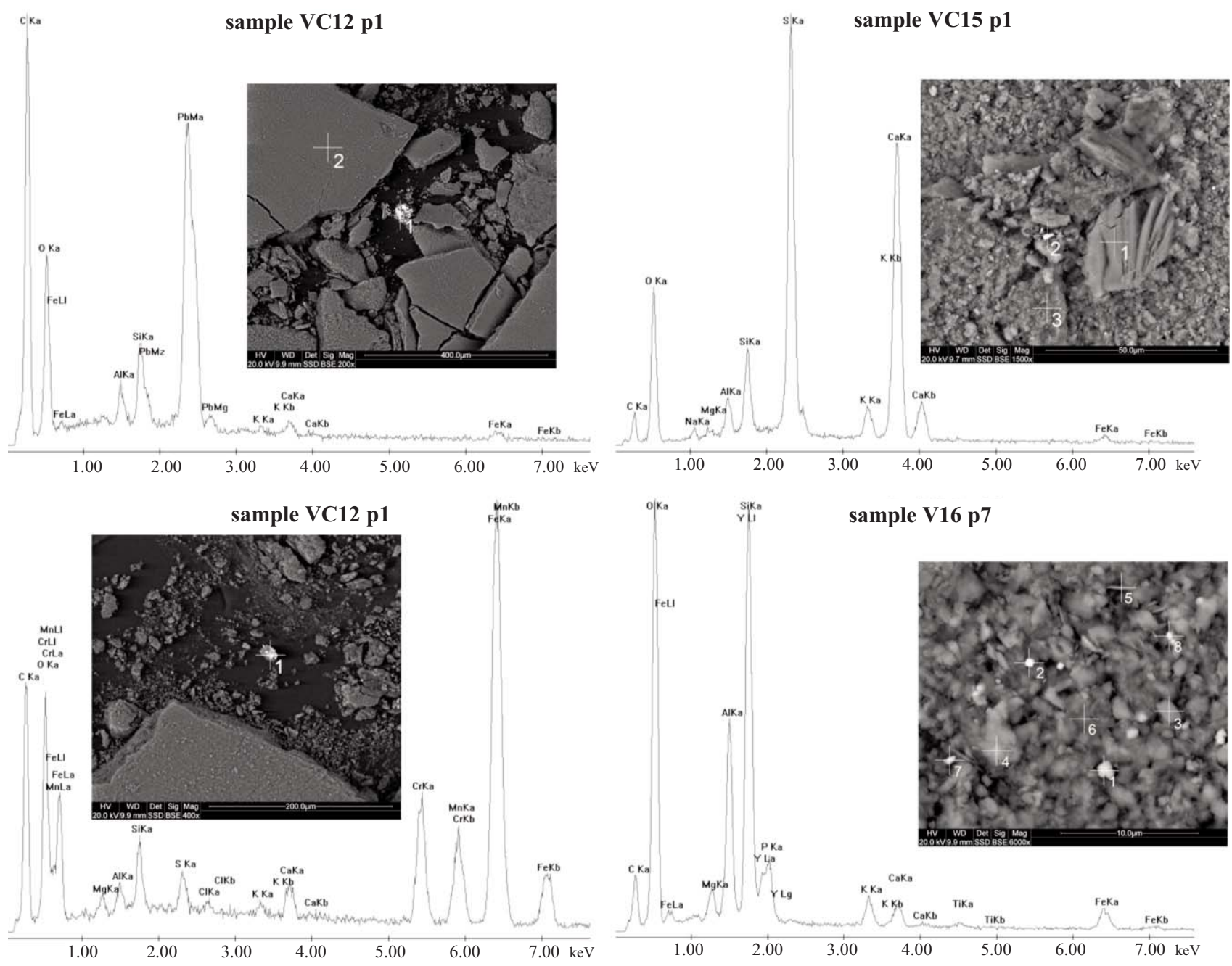

Fig. 4. Scanning electron micrographs and X-ray energy dispersive spectrum for the $<2 \mu \mathrm{m}$ size fraction of the Vistula River flood sediment selected samples: VC12, VC15, VC16. 

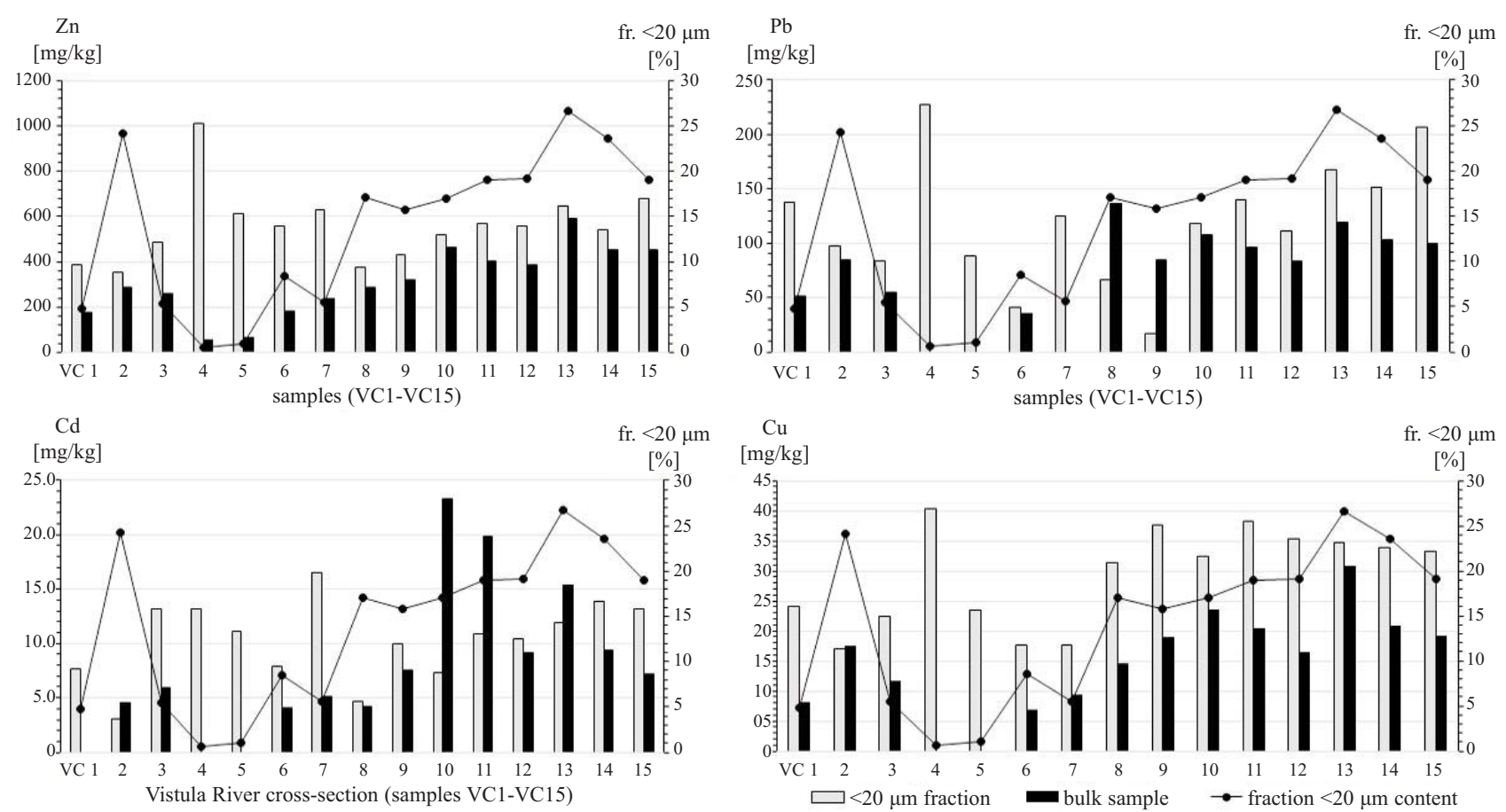

Fig. 5. Variability of the $<20 \mu \mathrm{m}$ fraction content and $\mathrm{Zn}, \mathrm{Pb}, \mathrm{Cd}$, and $\mathrm{Cu}$ concentrations in the flood sediment samples (bulk and $<20$ $\mu \mathrm{m})$ from the cross section (ca. $200 \mathrm{~m}$ wide) of the Vistula floodplain.
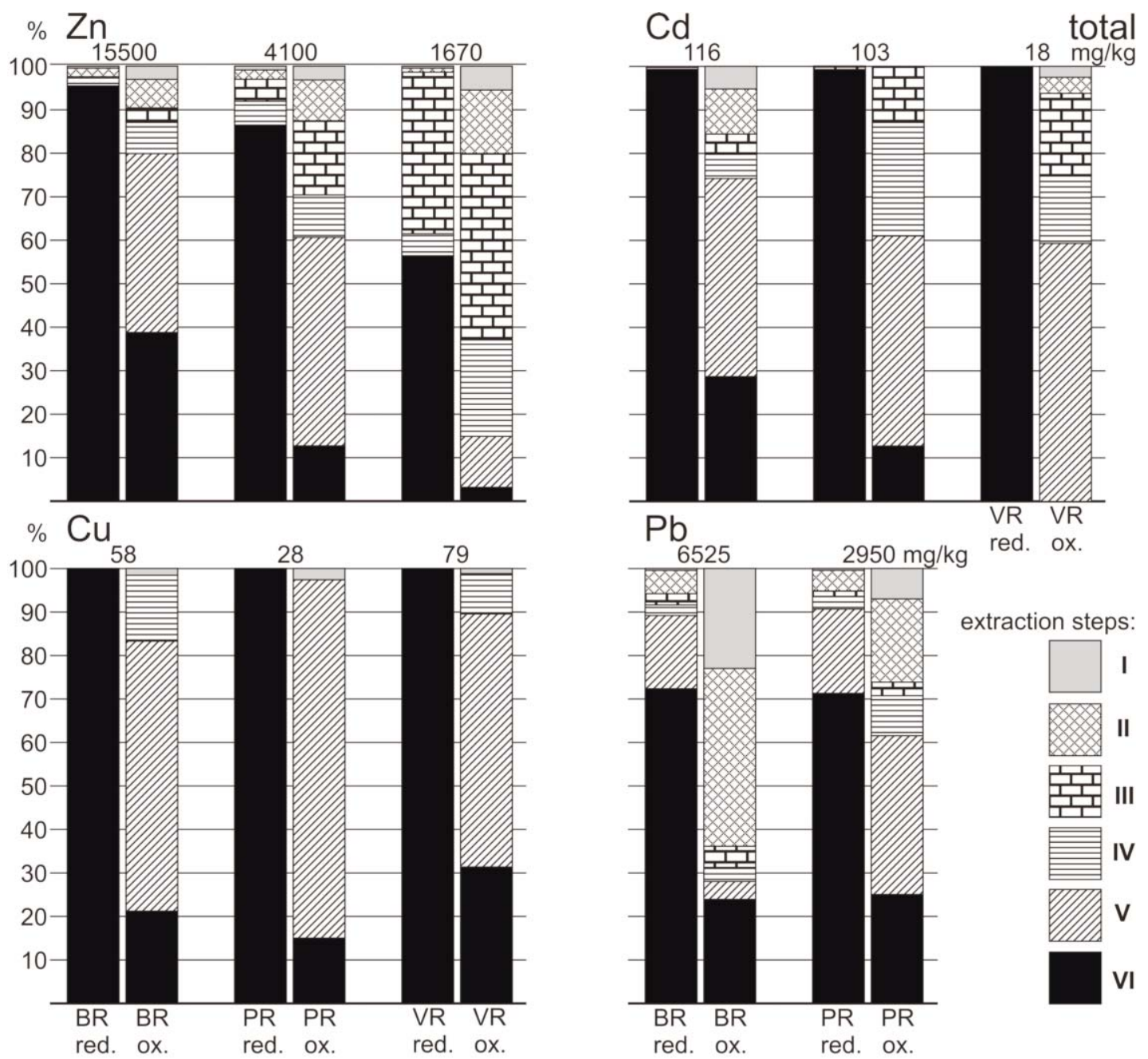

I exchangable, II carbonatic, III easily reducible, IV moderately reducible, V sulphitic / organic, VI residual

Fig. 6. Sequential extraction results for the selected Vistula floodplain samples (fraction $<20 \mu \mathrm{m}$ ), and sample V9 $(<2 \mu \mathrm{m})$. 

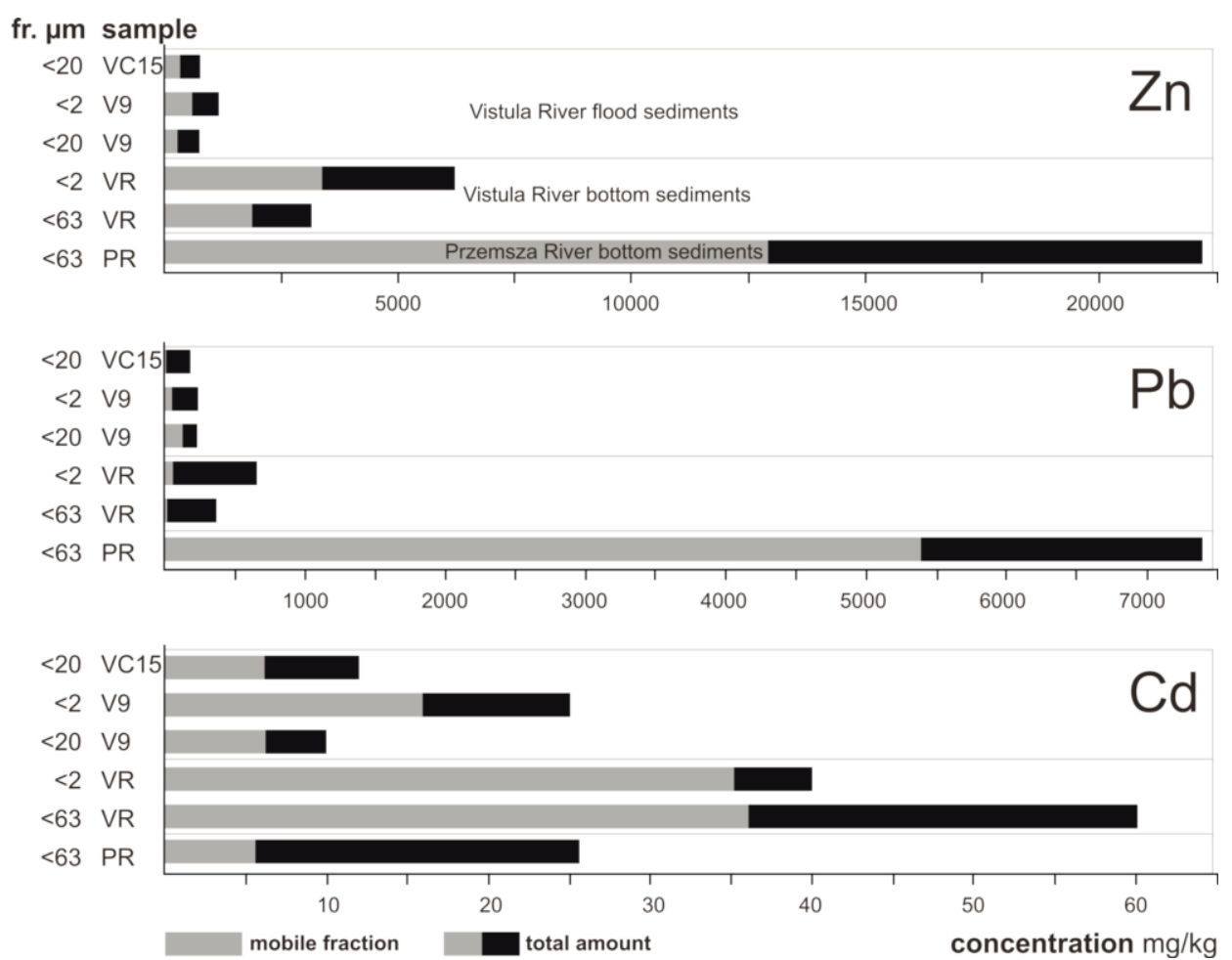

Fig. 7. Total and bioavailable concentrations of $\mathrm{Zn}, \mathrm{Pb}$, and $\mathrm{Cd}$ in the selected samples of the Vistula flood sediments and of the Vistula and Przemsza river bottom sediments, according to [35-37].

\section{Conclusions}

Sediments that are re-deposited on the floodplain in 2010 consist mainly of suspended matter and a mixture of fine-grained clay minerals, carbonates, and $\mathrm{Fe}-\mathrm{Mn}$ (hydro)oxide particles. They are contaminated mostly with $\mathrm{Zn}, \mathrm{Pb}$, and $\mathrm{Cd}$, exceeding geochemical background. Metal enrichment of the sediments originates from $\mathrm{Zn}-\mathrm{Pb}$ mining and smelting of ores deposited within the Przemsza River catchment area. An elevated salinity of the Vistula River water, caused by dewatering of coal mines, can influence the desorption processes, especially of $\mathrm{Cd}$ ions combined with exchangeable sites of fine-grained clay minerals.

From all the studied metals, $\mathrm{Cd}$ and $\mathrm{Zn}$ appear to be of particular concern due to their mobility and, therefore, bioavailability. Flood sediments re-deposited from the river channel went through oxidation processes that caused the metal sulfides to change to the sulfate forms, resulting in the acidification of the water-sediment system. The acidification will lead to further chemical degradation of alluvial soils, particularly in terms of reduced biological activity and in contaminated soil resulting from mobilization of potentially toxic metals.

\section{Acknowledgements}

Our work was supported by the AGH University of Science and Technology as Research Project No. 11.11.140.199.

\section{References}

1. DU LAING G., RINKLEBE B., VANDECASTEELE E., MEERS E., TACK F.M.G. Trace metal behavior in estuarine and riverine floodplain soils and sediments. A review. Sci. Total Environ. 417, (12), 3972, 2008.

2. SUN L., CHEN S., CHAO L., SUN T., Effects of flooding on changes in $\mathrm{EH}, \mathrm{pH}$ and Speciation of Cadmium and Lead in Contaminated Soil. B. Environ. Contam. Tox. 79, (5), $514,2007$.

3. RANKOWSKI M., SIEPAK M., ZIOŁA A., NOVOTNY K., VACULOVIC T., SIEPAK J. Vertical distribution of heavy metals in grain size fractions in sedimentary rocks: Mosina Krajkowo water well field, Poznań. Environ. Monit. Assess. 155, 493, 2009.

4. MALARZ R. Floods in Cracow. Geografia na codzień. 3. Konspekt 23, pp 1-3, 2005 [In Polish].

5. GRELA J. Analysis of the exploitation methods of the selected Upper Vistula's reservoirs during 2010 flood. European Symposium: Anti-Flood Defenses - Today's Problems. Paris-Orlean, 28-29.03.2012, pp. 1-10, 2012 [In Polish].

6. HELIOS-RYBICKA E., HOLDA A., JAROSZ E. Monitoring and quality assessment of selected physical and chemical parameters of the Sola River system, South Poland. Environmental Engineering. 10, (1), 45, 2005.

7. ALEKSANDER-KWATERCZAK U., HELIOS-RYBICKA E. Contaminated sediments as a potential source of $\mathrm{Zn}, \mathrm{Pb}$, and $\mathrm{Cd}$ for a river system in the historical metalliferous ore mining and smelting industry area of South Poland. Journal of Soils And Sediments. 9, (1), 13, 2009.

8. HELIOS-RYBICKA E. The role of clay minerals in the fixation of heavy metals in bottom sediments of the Upper 
Vistula River. Quarterly Geologia, AGH, Monograph. 32, 1986 [In Polish].

9. NOCOŃ W., BARBUSIŃSKI K, NOCOŃ K., KERNERT J. Variability analysis of the trace metal's concentration transported with suspended matter along the river. Ochrona Środowiska. 35, (1), 33, 2013 [In Polish].

10. CHIANG Y.W., SANTOS R.M., GHYSELBRECHT K., CAPPUYNS V., MARTENS J.A., SWENNEN R., VAN GERYEN T., MESSCHAERT B. Strategic selection of an optimal sorbent mixture for in-situ remediation of heavy metal contaminated sediments: framework and case study. J. Environ. Manage., 105, 1, 2012.

11. HELIOS-RYBICKA E., WOJCIK R. Impact of $\mathrm{Zn}-\mathrm{Pb}$ Historical and Present Mining and Smelting at Bukowno (Upper Silesia, Poland) on Contamination of Rivers and Soils. Pol. J. Environ. Stud. 20, (4), 76, 2011.

12. NOCOŃ W., NOCOŃ K., BARBUSIŃSKI K., KERNERT $\mathrm{J}$. The influence of zinc-lead ore mining industry on the level of the Biała Przemsza bottom sediments contamination. Architect. Civil Engin. Environ. 1, 65, 2012.

13. ASHAF M.A., MAAH M.J., YUSOFF I. Speciation of heavy metals in the sediments of former tin mining catchment. Iran. J. Sci. Technol. A2, 162, 2012.

14. YE F., HUANG X., ZHANG D., TIAN L, ZENG Y. Distribution of heavy metals in sediments of the Pearl River Estuary, southern China: implications for sources and historical changes. J. Environ Sci (China) 24, (4), 579, 2012.

15. GRUSZECKA A., WDOWIN M. Characteristics and distribution of analyzed metals in soil profiles in the vicinity of a postflotation waste site in the Bukowno region, Poland. Environ. Monit. Assess. 185, (10), 8157, 2013.

16. QUEVAUVILLER P.H., RAURET G., LOPEZ-SANCHEZ J.F., RUBINO R., URE A., MUNTAU H. Certification of trace metal extractable contents in a sediment reference material (CRM 601) following a three-step sequential extraction procedure. Sci. Total Environ. 205, 223, 1997.

17. OKORO H.K., FATOKI O.S., ADEKOLA F.A., XIMBA B.J., SNYMAN R.G. A Review of Sequential Extraction Procedures for Heavy Metals Speciation in Soil and Sediments. Open Access Scientific Reports. 1, (3), 2012.

18. NEMATI K., ABU BAKAR N.K., ABAS M.R., SOBHANZADEH E., LOW K.H. Comparison of unmodified and modified BCR sequential extraction schemes for the fractionation of heavy metals in shrimp aquaculture sludge from Selangor, Malaysia. Environ. Monit. Assess. 176, (1-4), 313, 2011.

19. NEMATI K., ABU BAKAR N.K., ABAS M.R., SOBHANZADEH E. Speciation of heavy metals by modified BCR sequential extraction procedure in different depths of sediments from Sungai Buloh, Selangor, Malaysia. J. Hazard. Mater. 192, 402, 2011.

20. NAJI A., ISMAIL A., ISMAIL A.R. Chemical speciation and contamination assessment of $\mathrm{Zn}$ and $\mathrm{Cd}$ by sequential extraction in surface sediment of Klang River, Malaysia. Microchem J. 95, (2), 285, 2010.

21. TUREKIAN K.K., WEDEPOHL K.H. Distribution of the Elements in some major units of the Earth's crust. Geological Society of America, Bulletin 72, 175, 1961.

22. HELIOS-RYBICKA E., STRZEBOŃSKA M. Distribution and chemical forms of heavy metals in the flood 1997 sediments of the Upper and Middle Odra River and its tributaries, Poland. Acta Hydroch. Hydrob. 27, 331, 1999.
23. ADAMIEC E., HELIOS-RYBICKA E. Assessment of total and mobile heavy metal content in the suspended matter and sediments of the Odra river system recommendations for river chemical monitoring. Pol. J. Environ. Stud. 11, (6), 675, 2002.

24. KRUOPIENE J., Distribution of Heavy Metals in Sediments of the Nemunas River (Lithuania). Pol. J. Environ. Stud. 16, (5), 715, 2007.

25. KELDERMAN P., OSMAN A.A. Effect of redox potential on heavy metal binding forms in polluted canal sediments in Delft (The Netherlands). Water Res. 41, (18) 4251, 2007.

26. BOJAKOWSKA I., GLIWICZ T. Cadmium in the sediments of the polish major rivers and their tributaries. Polish Geological Institute, Spec. Paper. 24, 15, 2008.

27. GUEGUEN C., DOMINIK J. Partitioning of trace metals between particulate, colloidal and truly dissolved fractions in a polluted river: the Upper Vistula River (Poland). Appl. Geochem. 18, 457, 2003.

28. ZHAO S., FENG C.H., WANG D.X., LIU Y.Z., SHEN Z.Y. Salinity increases the mobility of $\mathrm{Cd}, \mathrm{Cu}, \mathrm{Mn}$, and $\mathrm{Pb}$ in the sediments of Yangtze Estuary: Relative role of sediments' properties and metal speciation. Chemosphere 91, (7), 977, 2013.

29. www.wios.gov.pl

30. The Regulation of the Minister of Environment of 24 July 2006 on conditions to be met for the introduction of sewage into the water or soil, and on substances particularly harmful to the 13 aquatic environment (Journal of Laws no. 137, item 984, as amended). 2006.

31. DE JONGE M., TEUCHIES J., MEIRE P., BLUST R., BERVOETS L. The impact of increased oxygen conditions on metal-contaminated sediments part I: Effects on redox status, sediment geochemistry and metal bioavailability. Water Res., 46, (7), 2205, 2012.

32. IBRAGIMOW A., WALNA B., SIEPAK M. Effects of Flooding on the Contamination of Floodplain Sediments with Available Fractions of Trace Metals (Western Poland). Pol. J. Environ. Stud. 22, (1), 131, 2013.

33. HARTLEY W., DICKINSON, N.M.. Exposure of an anoxic and contaminated canal sediment: Mobility of metal(loid)s. Environ. Pollut., 158, (3), 649, 2010.

34. VINK J.P.M., HARMSEN J., RIJNAARTS H. Delayed immobilization of heavy metals in soils and sediments under reducing and anaerobic conditions; consequences for flooding and storage. Journal of Soils and Sediments, 10, (8), 1633, 2010.

35. HELIOS-RYBICKA E. The content and chemical forms of heavy metals in the river sediments of the Cracow area; the role of clay minerals. Environ. Technol. Lett. 4, 515, 1983.

36. HELIOS-RYBICKA E. Phase-specific bonding of heavy metals in sediments of the Vistula River, Poland. App. Geochem., (Suppl.) 2, 45, 1993.

37. ALEKSANDER-KWATERCZAK U. Trace metal distribution in the sediment cores of the selected rivers in Poland. AGH Krakow, Monographs. 114, 2007 [In Polish].

38. VIOLANTE A., COZZOLINO V., PERELOMOV L., CAPORALE A.G., PIGNA M. Mobility and bioavailability of heavy metals and metalloids in soil environments. J. Soil. Sci. Plant Nutr. 10, (3), 268, 2010.

39. MAGDI SELIM H. Dynamics and Bioavailability of Heavy Metals in the Rootzone, 2011.

40. HELIOS-RYBICKA E. Application of clay minerals in the synthesis of low-temperature sulfide minerals in relation to Kupferschiefer. Neues Jahrbuch Miner. Abh. 163, (2/3), 231, 1991. 